\title{
AKIBAT HUKUM KETIADAAN AKTA IKRAR WAKAF ATAS PERWAKAFAN TANAH
}

\author{
Faisal \\ Fakultas Hukum Universitas Muhammadiyah Sumatera Utara \\ Jl. Kap. Mukhtar Basri No. 3, Medan - Sumatera Utara \\ Email: faisal@umsu.ac.id
}

\begin{abstract}
Abstrak
Tanah wakaf adalah salah satu layanan sosial dalam agama Islam yang terkait erat dengan hukum negativitas, artinya sebagai seperangkat aturan yang mengatur cara menggunakan dan menggunakan bumi untuk kesejahteraan bersama semua orang. Lahirnya Undang-Undang Nmor 41 T2004 tentang Wakaf merupakan langkah untuk memperkuat status tanah wakaf dengan memberikan kepastian hukum atas tanah yang dimiliki wakaf. Berdasarkan Peraturan Pemerintah Nomor 42 Tahun 2004 tentang Harta Wakaf dijelaskan bahwa wakaf dalam posisinya sebagai salah satu lembaga hukum Islam, adalah lembaga keagamaan yang dapat digunakan sebagai sarana untuk pengembangan kehidupan beragama. Sifat penelitian yang digunakan adalah deskripsi jenis yuridis empiris. Sumber data yang digunakan dalam penelitian ini bersumber dari data sekunder yang terdiri dari bahan hukum primer, bahan hukum sekunder dan hukum tersier yang merujuk pada masalah; bagaimana kepastian hukum wakaf atas tanah yang tidak memiliki sertifikat wakaf. bagaimana kendala dan upaya hukum terhadap wakaf di darat yang tidak memiliki akta wakaf. Dengan diterbitkannya akta wakaf oleh PPAIW, kepastian hukum tanah wakaf memiliki kekuatan hukum dan lebih jauh lagi akan lebih kuat jika telah mengeluarkan sumpah wakaf dari Badan Pertanahan Nasional Nomor 422 Tahun 2004 3/SKB/BPN/2004 dalam Pasal 1 dan Pasal 2, Undang-Undang Nomor 24 Tahun 2004 tentang Lembaga Penjamin Simpanan.
\end{abstract}

\section{Kata Kunci: Akta, Ikrar, Wakaf, Tanah}

\section{Abstract}

Waqf land is one of the social services in Islamic religion that is closely related to the law of negativity, meaning as a set of rules governing how to use and use the earth for the common welfare of all the people. The birth of Law No. 41 of 2004 concerning Waqf is a step to reinforce the status of waqf land by providing legal certainty for the land owned by waqf. Based on Government Regulation No. 42 of 2004 concerning Waqf property explained that waqf in its position as one of the institutions of Islamic law, is a religious institution that can be used as a means for the development of religious life. The nature of the research used is a description of the type of empirical juridical. The data sources used in this study are sourced from secondary data consisting of primary legal material, secondary legal material and tertiary law that refers to the problem; how is the legal certainty of waqf on land that does not have a waqf certificate. how are obstacles and legal efforts against waqf on land that does not have a waqf deed. With the issuance of waqf pledge deed by PPAIW, the legal certainty of the waqf land is of legal strength and furthermore it will be even stronger if it has issued its waqf pledge from the National Land Agency Number 422 of 20043 SKB/BPN/2004 in Article 1 and Article 2, Law Number 24 of 2004 concerning Agency Endowments Fund.

Keywords: Deed, Pledge, Waqf, Land 
Jurnal Ilmu Hukum

FAKULTAS HUKUM UMSU
Akibat Hukum Ketiadaan...(Faisal)

Volume 3 Nomor 2, Juli-Desember 2018, 143-153 DOI: https://doi.org/10.30596/dll.v3i2.3154

\section{PENDAHULUAN}

Kesadaran hukum masyarakat merupakan suatu penelitian terhadap apa yang dianggap sebagai hukum yang baik dan yang tidak baik. Penelitian terhadap hukum tersebut didasarkan pada tujuannya, yaitu apakah hukum tadi adil atau tidak, oleh karena keadilanlah yang diharapkan oleh warga masyarakat. Hampir semua masyarakat ingin hidup pantas yang secara implisit berarti suatu keteratuaran, misalnya pada kehidupan sehari-hari, masing-masing sudah mempunyai suatu urutan kegiatan-kegiatan yang tersusun dalam daftar yang tersimpan di dalam pikirannya.

Apabila ada kegiatan-kegiatan yang dilakukannya, atau karena keadaan kemudian terlompati, maka kecenderungan bahwa urutan kegiatannya akan kacau dan yang bersangkutan merasakan ada sesuatu yang ganjil (Satjipto Raharjo. 2008, h. 117). Terdapat dua fungsi yang dapat dijalankan oleh hukum di dalam masyarakat, yaitu pertama sebagai sarana kontrol sosial dan kedua sebagai sarana untuk melakukan social engineering (Soerjono Soekanto \& Mustafa Abdullah 2007, h.235).

Wakaf sebagai perbuatan hukum sudah lama melembaga dan diperaktikkan di Indonesia. Diperkirakan lembaga wakaf ini sudah ada sejak Islam masuk ke Indonesia, kemudian berkembang seiring dan sejalan perkembangan agama islam di Indonesia. Perkembangan wakaf dari masa ke masa ini tidak didukung oleh peraturan formal yang mengaturnya, praktik perwakafan selama itu hanya berpedoman kepada kitab-kitab fiqih tradisional yang disusun beberapa abad yang lalu, banyak hal sudah tidak memadai lagi.

Wakaf berdasarkan Hukum Islam adalah menyerahkan tanah atau benda-benda lain yang dapat dimanfaatkan oleh umat islam tanpa merusak dan menghabiskan benda wakaf tersebut kepada seseorang atau badan hukum agar dapat dimanfaatkan untuk kepentingan umat islam. Sedangkan wakaf berdasarkan hukum agraria adalah pengalihan hak yang bersifat kekal, abadi dan untuk selamanya. Akibatnya tanah tersebut terlembagakan uantuk selamanya dan tidak dapat diahlikan haknya kepada pihak lain lagi, baik melalui cara jual beli, tukar.

Wakaf tanah merupakan salah satu ibadah sosial dalam agama islam yang erat kaitannya dengan hukum keagrariaan, artinya sebagai perangkat peraturan yang mengatur tentang bagaimana penggunaan dan pemanfaatan bumi untuk kesejahteraan bersama seluruh rakyat. Wakaf terkusus pada wakaf tanah adalah salah satu instrumen ekonomi islam yang sangat potensial dalam meningkatkan kesejahteraan soaial. Wakaf dapat menyelesaikan masalah sosial ekonomi jika dikelola secara profesional dan produktif.

Mengingat pentingnya persoalan tentang wakaf tanah ini, maka dinyatakan dalam Pasal 4 dan 5 Undang-Undang Nomor 41 Tahun 2004 Tentang Wakaf, menjelaskan bahwa wakaf bertujuan untuk memanfaatkan harta benda wakaf sesuain dengan fungsinya yaitu mewujudkan potensi dan manfaat ekonomis harta benda wakaf untuk kepentingan ibadah dan memajukan kesejahteraan umum. Wakaf yang tidak didaftarkan dan tidak disertifikatkan akan memicu timbulnya sengketa antara pihak yang mewakafkan dengan pihak ketiga yang 
Jurnal Ilmu Hukum

FAKULTAS HUKUM UMSU
Akibat Hukum Ketiadaan...(Faisal)

Volume 3 Nomor 2, Juli-Desember 2018, 143-153 DOI: https://doi.org/10.30596/dll.v3i2.3154

mengklaim memiliki tanah wakaf tersebut.

Berdasarkan pemaparan di atas, maka yang menjadi permasalahan dalam penelitian ini adalah, bagaimana kepastian hukum wakaf atas tanah yang tidak memiliki akta ikrar wakaf, bagaimana kendala hambatan dan upaya hukum terhadap wakaf atas tanah yang tidak memiliki akta ikrar wakaf?

\section{METODE PENELITIAN}

Jenis penelitian hukum dapat dibedakan menjadi penelitian hukum normatif dan penelitian hukum empiris atau sosiologis. Penelitian hukum normatif merupakan penelitian yang datanya bersumber pada data sekunder dan berhubung data penelitian ini adalah data sekunder, maka termasuk dalam jenis penelitian hukum normatif, Sifat penelitian ini adalah deskriptif. Sumber data penelitian berupa bahan hukum primer, bahan hukum sekunder dan bahan hukum tersier. Metode pengumpulan data dilakukan menggunakan teknik studi dokumen, yang dianalisis dengan menggunakan teknik analisis kualitatif.

\section{PEMBAHASAN}

\section{Kepastian Hukum Terhadap Tanah Wakaf yang Tidak Memiliki Akta Ikrar Wakaf}

Seiring dengan perubahan dan perkembangan pola pikir, pola hidup dan kehidupan manusia maka dalam pertanahan pun terjadi perubahan, terutama dalam hal kepemilikan dan penguasaannya dalam hal ini tentang kepastian hukum dan kepastian hak tanah yang sedang atau yang akan dimilikinya. Dengan adanya persoalan-persoalan, baik mengenai pertambahan penduduk maupun maupun perkrmbangan ekonomi, maka kebutuhan terhadap tanah dalam kegiatan pembangunan akan meningkat.

Berdasarkan kenyataan ini, tanah bagi penduduk Indonesia dewasa ini merupakan harta yang kekayaan yang paling tinggi nilainya dan juga merupakan sumber kehidupan, maka dari itu jengkal tanah dibela sampai titik darah penghabisan apabila hak tanahnya ada yang mengganggu. Untuk menjaga jangan sampai terjadi sengketa maka perlu diadakan pendaftaran tanah.

Pemberian jaminan kepastian hukum mengenai hak-hak atas tanah bagi seluruh rakyat Indonesia, yang menjadi salah satu tujuan diundangkannya UUPA dapat terwujud melalui dua upaya, yaitu:

a. Tersedianya perangkat hukum yang tertulis, lengkap dan jelas yang dilaksanakan secara konsisten sesuai dengan jiwa dan ketentuan-ketentuannya

b. Penyelenggaraan pendaftaran tanah yang memungkinkan bagi pemegang hak atas tanah untuk dengan mudah membuktikan hak atas tanah yang dikuasainya, dan bagi pihak yang berkepentingan, seperti calon pembeli dan calon kreditor, untuk memperoleh keterangan yang diperlakukan mengenai tanah yang menjadi objek perbuatan hukum yang akan dilakukan, serta bagi pemerintah untuk melaksanakan kebijaksanaan pertanahan.

Sebagai implementasi dari Pasal 19 ayat 1 dan 2 ini maka keluarkanlah Peraturan Pemerintah di bidang Pendaftaran Tanah yaitu Peraturan Pemerintah Nomor 10 Tahun 1961 
Jurnal Ilmu Hukum FAKULTAS HUKUM UMSU
Akibat Hukum Ketiadaan...(Faisal)

Volume 3 Nomor 2, Juli-Desember 2018, 143-153 DOI: https://doi.org/10.30596/dll.v3i2.3154

mengenai Pendaftaran Tanah. Dan pendaftran tanah dimaksud dijelaskan oleh Peraturan Pemerintah Nomor 10 Tahun 1961 Peraturan Pemerintah Nomor 10 Tahun 1961 tentang Pendaftaran Tanah pada Pasal 2 ayat 1-nya yaitu dilakukan desa demi desa atau daerah yang setingkat dengan itu. Dengan melihat konsepsi Pasal 19 ayat 1 dan 2 Undang-Undang Nomor 5 Tahun 1960 tentang Pokok Agraria (UUPA) serta Pasal 2 ayat 1 Peraturan Pemerintah Nomor 10 Tahun 1961 tentang Pendaftaran Tanah tersebut diatas, maka kita dapat mengetahui bahwa pendaftran tanah adalah perlu demi terciptanya kepastian hukum dan kepastian hak atas tanah. Dalam pelaksanaan pendaftran ini. Pemerintah akan melaksanakan secara sederhana dan mudah dimengerti dan secara berangsur-angsur.

Konsepsi logis dari semua itu adalah ayat 2 c Pasal 19 Peraturan Pemerintah Nomor 10 Tahun 1961 tentang Pendaftaran Tanah "Akan diberikan tanda bukti hak, di mana surat-surat bukti hak tersebut akan berlaku sebagai alat pembuktian yang kuat". Inilah fungsi pokok sebenarnya dari pendaftaran tanah. Jadi jelaslah sebenarnya bahwa tujuan pendaftaran tanah untuk memberikan kepastian hukum dan perlindungan hukum terhadap hak atas tanah. Pendaftran tanah adalah tugas dan beban pemerintah akan tetapi untuk mensukseskannya atau keberhasilannya sangat tergantung pada partisipasi aktif atau peranan masyarakat teruttama pemegang hak.

Adapun syarat yang dipenuhi agar pendaftaran tanah dapan menjamin kepastian hukum adalah: (Frabsisca Ani Rostina, 2018).

a. Tersedianya peta bidang tanah yang merupakan hasil pengukuran serta kadasteral yangg dapat dipakai untuk rekonstruksi batas dilapangan dan batas-batasnya merupakan batas yang sah menurut hukum. Peta bidang tanah yang merupakan hasil pengukuran tersebut dapat dikatakan memenuhi kaedah yuridis apbila bidang tanah yang dipetakan batas-batasnya telah dijamin kepastian hukumnya berdasarkan kesepakatan dalam penunjukan batas oleh pemilik dan pihak-pihak yang berbatasan (Pasal 17 Peraturan Pemerintah Nomor 24 Tahun 1997) ditetapkan oleh pejabat yang berwenang (Pasal 18 Peraturan Pemerintah Nomor 24 Tahun 1997) dan diumumkan secara langsung kepada masyaakat setempat untuk memberikan kesempatan kepada pihak lain menyampaikan keberatannya (Pasal 26 Peraturan Pemerintah Nomor 24 Tahun 1997).

b. Tersedianya daftar umum bidang-bidang tanah yang dapat membuktikan pemegang hak yang terdaftar sebagai pemegang hak yang sah menurut hukum. Daftar umum bidang tanah diseediakan pada Kantor Pertanahan yang menyajikan data fisik dan data yuridis bidang tanah yang terdiri dari peta pendaftaran, daftar tanah, surat ukur, buku tanah dan daftar nama (Pasal 33 Peraturan Pemerintah Nomor 24 Tahun 1997) dan setiap orang yangg berkepentingan berhak mengetahui data fisik dan data yuridis yang tersimpan dalam daftar umum (Pasal 34 Peraturan Pemerintah Npmpr 24 Tahun 1997).

c. Terpeliharanya daftar umum pendaftaran tanah yang selalu mutakhir, yakni setiap perubahan data mengenai hak atas tanah seperti peralihan hak tercatat dalam daftar umum. 
Jurnal Ilmu Hukum

FAKULTAS HUKUM UMSU
Akibat Hukum Ketiadaan...(Faisal)

Volume 3 Nomor 2, Juli-Desember 2018, 143-153 DOI: https://doi.org/10.30596/dll.v3i2.3154

Sistem peraturan tanah yang dianut oleh Undang-Undang Nomor 5 Tahun 1960 tentang Pokok Agraria adalah sistem publikasi negatif yang bertendensi positif, artinya negara tidak menjamin mutlk kebenaran data yang disajikan dalam sertifikat, namun selama tidak ada orang lain yang mengajukan gugatan kepengadilan sebagai pihak yang lebih berhak, maka data dalam sertifikat adalah tanda bukti hak yang kuat (Pasal 19 ayat 2 UUPA).

Kepastian hukum disini meliputi kepastian objek, kepastian hak, dan kepastian subjek dalam rangka mendapatkan dan atau memberikan perlindungan hukum atas kepemilikan tanah baik yang belum bersertifikat maupun yang sudah bersertifikat. Dengan kata lain kepastian disini adalah kepastian mengenai orangnya atau badan hukum yang menjadi pemegang hak atas tanah dan kepastian mengenai letak, batas-batas serta luasnya bidang tanah. Dengan memperhatikan kemampuan pemerintah, maka pelaksanaan pendaftaran tanah dilakukan secara bertahap. Sebagai langkah awal dilakukan pengukuran desa demi desa untuk memenuhi ketersediaan Peta Dasar Pendaftaran Tanah yang memuat titik-titik dasar tehnik dan unsur-unsur geografis serta batas fiksik bidang-bidang tanah.

Pada wilayah yang belum dilakukan secara sistematik, peta dasar pendaftaran tanah sangat diperlukan untuk mengidentifikasi dan menetapkan letak tanah yang akan didaftarkan secara sporadik, dan selanjutnya menjadi dasar untuk pembuatan peta pendaftran. Sehubungan dengan pemberian kepastian hukum mengenai hak-hak atas tanah, baik mengenai subjek maupun objeknya, maka pemerintah mengharuskan dilakukan pengumuman mengenai hak-hak atas tanah, yang meliputi: (Rifai, 2018).

a. Pengumuman mengenai subjek yang menjadi pemegang hak yang dikenal sebagai asas publisitas dengan maksud agar masyarakat luas dapat mengetahui tentang subjek dan objekatas satu bidang tanah. Adapun implementasi dari asas publisitas ini adalah dengan mengadakan pendaftran tanah.

b. Menetapan mengenai letak, batas-batas, dan luas bidang-bidang tanah yang dipunyai seseorang atas sesuatu hak atas tanah, dikenal sebagai asas spesialitas dan implementasinya adalah dengan mengadakan Kadaster.

Maka dengan demikian, maka seseorang yang hendak membeli suatu hak atas tanah tidak perlu melakukan penyidikan sendiri, karena keterangan mengetahui subjek dan objek atas suatu bidang tanah dapat diperolah dengan mudah pada instansi pemerintah yang ditugaskan menyelenggarakan Pendaftaran Tanah.

Jadi kalau dilihat dari tujuan pendaftaran tanah baik melalui Peraturan Pemerintah Nomor 10 Tahun 1961 maupun Nomor 24 Tahun 1997 maka status kepemilikan hak atas tanah bagi warga Negara Indonesia akan terjamin dan akan tercipta suatu kepastian baik mengenai, subjeknya, objeknya maupun hak yang melekat diatasnya termasuk dalam hal ini peralihan hak atas tanah. Hanya saja Kantor Pertanahan harus lebih aktif lagi mensosialisasikan kegiatan pendaftaran tanah baik mengenai tata cara, prosedur maupun biayanya serta pentingnya pendaftaran tanah ini bagi pemegang hak.

Maka lebih penting lagi Kantor Pertanahan harus senantiasa melakukan pemutakhiran data tanah agar tidak terjadi overlapping dalam pemberian haknya atau pendaftran haknya yang dapat menimbulkan masalah hukum yaitu sengketa/perkara yang disebabkan oleh 
Akibat Hukum Ketiadaan...(Faisal)

Volume 3 Nomor 2, Juli-Desember 2018, 143-153 DOI: https://doi.org/10.30596/dll.v3i2.3154

adalanya sertifikat ganda atau sertifikat palsu. Kantor Pertanahan haruslah senantiasa memutakhirkan datanya terutama buku tanah sebagai bank data.

Pemberian jaminan kepastian hukum mengenai hak-hak atas tanah bagi seluruh rakyat Indonesia, yang menjadi salah satu tujuan diundangkan UUPA dapat terwujud melalui upaya, yaitu: (Urip Santoso. 2010, h. 2).

a. Tersedianya perangkat hukum yang tertulis, lengkap dan jelas yang yang dilaksanakan secara konsisten sesuai dengan jiwa dan ketentuan-ketentuannya.

b. Penyelenggaraan pendaftran tanah yang memungkinkan bagi pemegang hak atas tanah untuk dengan mudah membuktikan hak atas tanah yang dikuasainya, dan bagi pihak yang berkepentingan, seperti calon pembeli dan calon kreditor, untuk memperoleh keterangan yang diperlukan mngenai tanah yang menjadi objek perbuatan hukum yang akan dilakukan, serta bagi pemerintah untuk melaksanakan kebijaksanaan pertanahan.

Pemerintah telah mengeluarkan Undang-Undang yang mengatur masalah perwakafan namun praktik wakaf yang terjadi dalam kehidupan masyarakat belum sepenuhnya berjalan tertib dan efesien, sehingga dalam berbagai kasus harta benda wakaf tidak terpelihara sebagaimana mestinya, telantar atau beralih ketangan pihak ketiga dengan cara melawan hukum keadaan demikian,tidak hanya karena kelalaian atau ketidakmampuan nadzhir dalam mengelola dan mengembangkan harta benda wakaf tetapi juga karena sikap masyarakat yang kurang peduli atau belum memahami status harta benda wakaf yang seharusya dilindungi demi untuk kesejahteraan umum sesuai dengan tujuan, fungsi, dan peruntukan wakaf.

Keputusan bersama Menteri Agama Republik Indonesia dan Kepala Badan Pertanahan Nasional Nomor 422 Tahun 2004 3/SKB/BPN/2004 di Pasal 1 meningkatkan kegiatan pensertifikatan tanah wakaf, memperioritaskan penyelesaian pensertifikatan tanah wakaf yang permohonannya telah diajukan ke Kantor Pertanahan seluruh Indonesia. Dan di Pasal 2 melakukan pendataan dan inventarisasi letak dan batas tabah secara bersama-sama, mempercepat penyelesaian Akta Ikrar Wakaf, mempercepat penyelesaian pensertifikatan tanah wakaf.

Hubungan hukum antara si pewakif dengan PPAIW dapat dilihat pada Undang-Undang Nomor 41 Tahun 2004 dimana wakif berkewajiban melakukan Ikrar Wakaf baik lisan maupun tulisan dihadapan PPAIW dan 2 (dua) orang saksi (Pasal 17). Dan Pasal 5 Peraturan Pemerintah Nomor 28 Tahun 1977 tentang Perwakafan Tanah Milik menentukan setiap pihak yang akan mewakafkan tanahnya harus menyatakan kehendaknya untuk mewakafkan (menyampaikan ikrar wakaf) kepada Nadzhir di hadapan Pejabat Pembuat Akta Ikrar Wakaf (PPAIW, dan selanjutnya setelah dibuat Akta Ikrar Wakafnya berdasarkan ketentuan Pasal 32 Undang-Undang Nomor 41 Tahun 2004 tentang Wakaf dan Pasal 10 Peraturan Pemerintah Nomor 28 Tahun 1977 tentang perwakafan tanah milik, Pejabat Pembuat Akta Ikrar Wakaf (PPAIW) berkewajiban untuk mendaftarkan tanah wakaf tersebut kepada Badan Pertanahan Nasional setempat untuk diterbitkan sertifikat tanah wakafnya. 
Jurnal Ilmu Hukum

FAKULTAS HUKUM UMSU
Akibat Hukum Ketiadaan...(Faisal)

Volume 3 Nomor 2, Juli-Desember 2018, 143-153 DOI: https://doi.org/10.30596/dll.v3i2.3154

Oleh karena itu Undang-undang Nomor 41 Tahun 2004 tentang wakaf mewajibkan nadzhir membawa wakif di hadapan Pejabat Pembuat Akta Ikrar Wakaf (PPAIW) untuk melaksanakan ikrar wakaf yang selanjutnya oleh Pejabat Pembuat Akta Ikrar Wakaf (PPAIW) dibuatkan Akta Ikrar Wakaf (AIW) atas tanah dimaksud.

Lebih lanjut Pasal 5 Peraturan Pemerintah Nomor 28 Tahun 1977 tentang Perwakafan Tanah Milik, ditentukan bahwa:

a. Pihak yang mewakafkan tanah harus mengikrarkan kehendaknya secara jelas dan tegas kepada Nadzhir dihadapan Pejabat Pembuat Akta Ikrar Wakaf sebagaimana dimaksud Pasal 9 ayat 2 yang kemudian menuangkannya dalam bentuk Akta Ikrar Wakaf, dengan disaksikan oleh sekurang-kurangnya 2 (dua) orang saksi.

b. Dalam keadaan tentunya, penyimpangan dari ketentuan dimaksud dalam ayat 1 dapat dilaksanakan setelah terlebih dahulu mendapat persetujuan Menteri Agama.

Ketentuan mengenai perwakafan berdasarkan syariah dan peraturan perundangundangan dicantumkan kembali dalam Undang-Undang Nomor 41 tahun 2004 dengan berups perstursn baru. Dikemukakan pula dengan berlakunya Undang-Undang Nomor 41 tahun 2004 tersebut, semua peraturan perundang-undangan yang mengetur mengenai perwakafan masih tetap berlaku sepanjang tidak bertentangan dan/atau belum diganti dengan peraturan yang baru dan berbeda yang terdapat dalam Undang-Undang Nomor 41 tahun 2004 bila dibandingkan dengan Peraturan Pemerintah Nomor 28 tahun 1977 maupun Kompilasi Hukum Islam, walaupun banyak pula kesamaannya. Dapat dikatakan bahwa Undang-Undang Nomor 41 Tahun 2004 mengatur subtansi yang lebih luas dan bila dibandingkan dengan peraturan perundang-undangan yang ada sebelumnya.

Masih banyaknya tanah wakaf yang tidak memiliki Ikrar Wakaf dan juga sertifikat wakaf, serta mengalami permasalahan maka kementerian agama tidak dapat turut serta dalam pemecahan kasus tersebut begitu juga dengan Badan Wakaf Indonesia (BWI) karena bukan wilayah kinerja mereka. Akan tetapi, dengan budaya masyarakat Indonesia yaitu musyawarah untuk mufakat, dengan kasus adanya kebijakan pemerintah dalam perubahan Rencana Umum Tata Ruang (RUTR) yang didalamnya ada tanah wakaf akan tetapi tidak memiliki ikrar wakaf dan tidak didaftarkan maka metode musyawarah untuk mufakat dapat diambil oleh nadzhir dengan pihak terkait terhadap tanah wakaf yang terganggu tersebut untuk memperoleh hasil yang sama-sama menguntungkan.

Negara Indonesia adalah negara hukum yang menjunjung tinggi hukum, sehingga segala pelanggaran dan kejahatan yang dilakukan akan ditindak dan diberi sanksi, baik sanksi pidana maupun sanksi administrasi sesuai dengan perbuatan yang dilakukan. Demikian pula pelanggaran yang dilakukan dalam permasalahan wakaf terutama wakaf tanah. Ada 2 (dua) bentuk sanksi yang diberikan atas pelanggaran wakaf yakni bentuk sanksi administratif dan sanksi pidana. Berdasarkan Undang-Undang Nomor 41 tahun 2004 ketentuan pidana dalam hukum wakaf masih terbatas sasaran Nadzhir dan Pejabat Pembuat Akta Ikrar Wakaf. Hal ini dijelaskan pada Pasal 67 ayat 1 dan ayat 3: 
Jurnal Ilmu Hukum

FAKULTAS HUKUM UMSU
Akibat Hukum Ketiadaan...(Faisal)

Volume 3 Nomor 2, Juli-Desember 2018, 143-153 DOI: https://doi.org/10.30596/dll.v3i2.3154

a. Setiap orang yang dengan sengaja menjaminkan, menghibahkan, menjual, mewariskan, mengelihkan dalam bentuk pengalihan hak lainnya harta bend wakaf yang telah diwakafkan sebagaimana dimaksud dalam Pasal 40 atau tanpa izin menukar harta benda wakaf yang telah diwakafkan sebagaimana dimaksud dalam Pasal 41, dipidana dengan pidana penjara paling lama 5 (lima) tahun dan/atau pidana paling banyak Rp. 500.000.000,00 (lima ratus juta rupiah).

b. Setiap orang yang dengan sengaja mengubah peruntukan harta benda wakaf tanpa izin sebagaimana dimaksud Pasal 44, dipidana dengan pidan penjara paling lama 4 (empat) tahun dan/atau denda paling banyak Rp. 400.000.000,00 (empat ratus juta rupiah).

c. Setiap orang yang dengan sengaja menggunakan atau mengambil fasilitas atas hasil pengolaan dan pengembangan harta benda wakaf melebihi jumlah yang ditentukan sebagaimana dimaksud dalam Pasal 12, dipidana dengan pidana penjara paling lama 3 (tiga) tahun atau pidana denda paling banyak Rp. 300.000.000,00 (tiga ratus juta).

Pasal 32 ayat (2) PP. 24 Tahun 1997 menyatakan bahwa dalam hal atas suatu bidang tanah sudah diterbitkan setifikat secara sah atas nama orang atau badan hukum yang memperoleh tanah tersebut dengan itikad baik dan secara nyata menguasainya, maka pihak lain yang merasa mempunyai hak atas tanah itu tidak dapat lagi menuntut pelaksanaan hak tersebut apabila dalam waktu 5 (lima) tahun sejak diterbitkannya sertifikat itu tidak mengajukan keberatan secara tertulis kepada pemegang sertifikat dan Kepala Kantor Pertanahan yang bersangkutan atau pun tidak mengajukan gugatan pada pengadilan mengenai penguasaan tanah atau penerbitan sertifikat tersebut.

\section{Dampak Hukum Terhadap Tanah Wakaf Yang Tidak Memiliki Akta Ikrar Wakaf}

Dalam praktik perwakafan sehari-hari, banyak persoalan perwakafan yang timbul. Penyebab timbulnya persoalan ini antara lain karena ikrar wakaf tidak memenuhi ketentuan sebagaimana mestinya. Pewakaf mewakafkan hartanya hanya dengan lisan saja kepada nadzhir (biasanya seorang guru agama atau tokoh agama), bahkan terkadang tanpa ada saksi sama sekali. Akibatnya, setelah pewakaf dan/atau nadzhir meninggal dunia sering terjadi persoalan. Antara nadzhir dengan keluarga atau ahli waris pewakaf. Atau sebaliknya nadzhir meninggal dunia, kemudian harta wakaf dikuasai oleh keluarga atau ahli waris nadzhir. Akhirnya banyak terjadi harta wakaf yang tidak jelas status dan keberadaannya lagi (M. Sofyan Lubis, 2018).

Hambatan yang umum dialami dunia perwakafan di Indonesia adalah minimnya kemampuan para nadzhir wakaf untuk memecahkan persoalan tersebut. Kemampuan pengelolaan tanah yang minim. Di samping karena faktor letak yang tidak strategis secara ekonomi dan kondisi tanah,hambatan ynag cukup mencolok untuk mengelola tanah wakaf secara produktif adalah kemampuan Sumber Daya Manusia (SDM)penggarap yang tidak professional (melalui: www.penyuluhankuakrembangan.com).

Kendala pemahaman untuk mengalihkan tanah-tanah yang atau sasaran lain yang strategis secara ekonomis masih menjadi hambatan yang nyata. Hal ini bisa dimaklumi karena 
Jurnal Ilmu Hukum FAKULTAS HUKUM UMSU
Akibat Hukum Ketiadaan...(Faisal)

Volume 3 Nomor 2, Juli-Desember 2018, 143-153 DOI: https://doi.org/10.30596/dll.v3i2.3154

adanya pemahaman yang kuat dan mendalam bahwa wakaf merupakan harta yang bersifat abadi dimana kepemilikannya dikembalikan penuh kepada Allah sebagaimana dikembalikan kepada arti wakaf itu sendiri, yaitu harta yang berhenti untuk Allah, sehingga apapun kondisi harta wakaf tersebut harus dibiarkan dan tidak boleh dibah-ubah oleh alasan apapun.

Masalah ini sebenarnya terbuka peluang yang cukup besar untuk mengelola tanah-tanah wakaf yang tersedia di lingkungan umat Islam. Tentu saja tidak cukup sekedar menyegarkan kembali pemahaman umat Islam tentang wakaf itu sendiri, tapi yang paling penting dan mendesak adalah bagaimana SDM perwakafan mampu mengelola, mengembangkan, mendistribusikan dan menjaga agar wakaf tetap mempunyai manfaat bagi kesejahteraan umat Islam khususnya dari umat lain pada umumnya.

Penguatan Lembaga Kantor Urusan Agama (KUA) ini pada tahap awal bisa dikhususkan pada 2 (dua) aspek yaitu:

a. Aspek SDM (Sumber Daya Manusia)

Pada aspek ini SDM ini titik tekannya pada dua hal juga yaitu:

1) Penugasan personil di KUA yang secara khusus mempunyai tugas sebagai pengelola wakaf, diharapkan dengan adanya kekhususan tugas akan semakin mempertajam dan memperbaiki pengolaan data-data wakaf di KUA.

2) Pelatihan dan pembinaan bagi personil yang ditugaskan khusus sebagai pengelola wakaf, dengan adanya pelatihan dan kontinyu personil KUA tersebut akan mampu mendorong pensuksesan program pemberdayaan wakaf di masyarakat.

b. Aspek Pendanaan/Dukungan Anggaran

Memang harus diakui dukungan anggaran bagi terlaksananya program atau kegiatan yang bertujuan untuk sosialisasi, pendataan, melegalisasitanah wakaf baik prmbuatan Akta Ikrar Wakaf maupun pensertifikatannya dan pemberdayaan wakaf itu sendiri sangat mutlak dibutuhkan.

\section{KESIMPULAN DAN SARAN Kesimpulan}

Kepastian hukum disini meliputi kepastian objek, kepastian hak, dan kepastian subjek dalam rangka mendapatkan dan atau memberikan perlindungan hukum atas kepemilikan tanah baik yang belum bersertifikat maupun yang sudah bersertifikat. Dengan kata lain kepastian disini adalah kepastian mengenai orangnya atau badan hukum yang menjadi pemegang hak atas tanah dan kepastian mengenai letak, batas-batas serta luasnya sebidang tanah.

Dalam rangka penerbitan administrasi tanah wakaf, pengadministrasian tanah wakaf tidak hanya sebatas pada pembuatan Akta Ikrar Wakaf saja, namun beru berlanjut pada tahap pendaftaran di Kantor Badan Pertanahan Nasional hingga diterbitkannya sertifikat tanah wakaf. Jika prosesnya hanya sampai pada pembuatan Akta Ikrar Wakaf saja, maka dapat disimpulkan bahwa proses administrasi perwakafan tanah menjadi tidak sempurna. Hal ini mengakibatkan tanah wakaf tidak memiliki kekuatan hukum dan tidak memicu permasalahan 
di masa yang akan datang karena ada peluang yang bisa dijadikan dasar untuk menarik tanah wakaf tersebut, bagi pihak ahli waris atau mereka yang mengaku memiliki hubungan keluarga dengan wakif.

\section{Saran}

Sebaiknya kepada Badan pertanahan Nasional seperti kantor Pertanahan di Kecamatan Medan Timur untuk melaksanakan perintah Undang-Undang terhadap tanah wakaf para petugas kantor pertanahan melakukan pengecekan berkas dari pemohon dan pengecekan bukti kepemilikan yang berada di Kecamatan Medan Timur.

Seharusnya kepada pewakaf atau nadzhir untuk mendaftarkan akta ikrar wakaf berdasrkan peraturan pemerintah dan mempercayai Nadzhir dalam hal ini Kantor Urusan Agama sebagai Pejabat Pembuat Akta Ikrar Wakaf (PPAIW) dalam pendaftaran wakaf pada kantor pertanahan serta memperoleh pemberitahuan dari Nadzhir tentang kepastian hukum terhadap tanah wakaf setelah adanya Undang-Undang Nomor 41 Tahun 2004 setelah didaftarkan pada kantor pertanahan. 


\section{DAFTAR PUSTAKA}

Kitab Undang-Undang Hukum Perdata.

Kompilasi Hukum Islam.

Lubis, M. Sofyan. (2018) diakses pada tanggal 26 September 2018 melalui http://www.google.co.id

Peraturan pemerintah Nomor 42 Tahun 2006 tentang Peraturan Pelaksanaan Undang-Undang Nomor 41 Tahun 2004 tentang Wakaf.

Raharjo, Satjipto. (2008). Hukum dan Masyarakat. Bandung: Angkasa.

Rifai. (2018). Diakses pada tanggal 26 September 2018 melalui http://www.penarifai.blogspot.com

Rostina, Frabsisca Ani (2018). Diakses pada tanggal 26 September 2018 melalui lib.ui.ac.id/file?file $=$ digital/

Soekanto, Soerjono., \& Abdullah, Mustafa. (2007). Sosiologi Hukum dalam Masyarakat. Jakarta: Raja Grafindo Persada.

Susanto, Urip. (2016). Pejabat Pembuat Akta Tanah. Jakarta: PT. Kharisma Putra Utama.

Undang-Undang Nomor 41 Tahun 2004 tentang Wakaf. 